\title{
Non-violence: An Imperative for a Flourishing Collective Life
}

\author{
Ahimsa sabbbhuya khemankari-Buddha \\ (Non-violence ensures well-being of all living beings)
}

Recognizing the contributions of Mahatma Gandhi to humanity and world peace the United Nations has declared his birthday, 2nd October, as the International Day of Non-violence. This gesture is a public acknowledgment of the need to have a paradigm shift in our approach to social problems. It is happening at a time when world is immeasurably suffering from the real and potential threat of violence at all levels of our existence. In the Indian tradition harming any living being has been termed as an evil (Papaya parapidanam) and non-violence or Ahimsa is treated as the greatest Dharma or virtue (Ahimsa paramo dharmah -Mahabharata). Buddhism and Jainism have given special emphasis on the practice of non-violence. Other religions like Christianity, Islam, Sikhism, and thinkers like Confucius too have emphasized the significance of non-violence.

In modern times Gandhi demonstrated the use of nonviolence in the freedom struggle of India and has shown way to the people in other parts of the world. According to Gandhi non-injury or not entertaining ill feeling or hostility toward others due to anger, hatred, jealousy, conflict, or any act driven by selfishness is non-violence. In addition he gives a positive view of it and asks to observe love, kindness, sympathy, service and cooperation with others. Non-violence requires recognizing the existence of others and feeling of shared or common nature which generates the experience of viewing others as similar to one's own self (Atmopamyata).

Notwithstanding the widespread recognition of nonviolence as an important principle human history is replete with the incidents of violence. The 20th century has been the bloodiest century in human history with an estimated toll of killings of human lives going beyond 100 million. In particular its last decade has witnessed organized violence and cruelty. The beginnings of 21 st century are in no way better. Large scale human suffering is being seen in different parts of the world.

With time the technology and severity of violence have assumed greater degree of sophistication and are now causing large scale threat to global well-being. Its range encompasses many shades - from cool instrumental kinds of violence to hot hostile aggression. Unfortunately both of these forms are dominating human lives. In particular, its strategic deployment in terrorist activities involving large scale collective violence is becoming a matter of serious concern. Violence is evident in its visible and explosive forms and also in its disguised form as manifested in our day-to-day interactions, vocabulary and behavior.

Research on aggression has indicated that the thought or act of violence relates to anger which is one of the most commonly experienced social emotions. Many consider it as a primary emotion on the ground that it has evolutionary significance, has cross-cultural universality, and the autonomic patterns related to it are quite distinct from other emotions. This is often mistaken to suggest that human nature has an intrinsic element of anger and violence.

In everyday life people frequently express anger, become targets of others' anger and witness it in different forms (e.g. real life, literature or media). Usually anger is marked by a set of uncomfortable cognitions and affect (e.g. irritation, annoyance, rage and heightened activation), physiological reactions, expressions and consequences. The common elicitors of anger include insult, injustice, inequity, betrayal, unfairness, blocking of goals, unmet expectations, incompetent actions of others, and being target of another's aggression.

Anger, being a negative and socially undesirable emotion, is often denied, projected, suppressed or displaced. While anger is often thought of as a response to happenings in the external environment it is also intrapsychic and people do engage in it with a deliberate plan and justification. Collective violence to eliminate ethnic and caste groups illustrates it. An analysis of anger experiences brings in the centrality of the involvement of ego or limited bodily self. It often occurs as a defense reaction to the real, implied or imagined threat to selfhood.

The sites of anger are quite varied and its distribution in society often depends on the degree of power and control enjoyed by the people. Anger provocation differs across groups based on gender, age and social class. It has been found that work and family roles and interpersonal dynamics often play crucial part in creating the circumstances leading to anger. In any case anger does have disparaging consequences for individuals and communities.

The theoretical explanations of aggression and violence are quite diverse. The biological view endorsed by instinct theorists holds that aggression is an innate instinctual energy. The adaptive value of aggression has been emphasized by ethologists and evolutionary theorists who locate it in 
evolutionary history. This view implies that the mechanisms of aggression are inherited. The search for brain mechanisms does show correlations between aggressive behavior and neuro-chemical changes in certain areas of human brain. The individual and culture level variation in aggression, however, implies that violent behavior cannot be treated as genetically programmed into human nature. The evidence defies any kind of biological reductionism and favors the view that the shaping of aggression is a function of nature as well as nurture. The social learning view upholds that aggression is a learned form of behavior which subsequently may become a stable disposition. It has also been noted that the environmental conditions such as pain, heat, arousal, and presence of aggressive cues and cognitive priming provoke aggressive activities.

While locating aggression many psychologists hold that frustration constitutes a major immediate cause of anger. Frustration-aggression hypothesis is advanced in different guises by the lay people as well as psychologists. In contemporary scenario relative deprivation based on social comparison has become a major source of frustration, particularly when an individual or group assumes genuine claim and entitlement. However, the expression of aggression can be direct or indirect. We learn to inhibit direct aggression and show displacement of our hostilities on other targets. The cognitive neo associationist view proposes that aversive events generate negative affect or emotional readiness to aggress, which in turn, activates aggressive behaviors.

In social life anger and aggression have earned certain degree of legitimacy and many parents wish that their children must have a certain degree of aggressiveness. They justify this desire in the context of competitive spirit and predominance of individualism in contemporary period. This also reflects the values of consumerist, materialist and selfcentered orientation and reinforces a strong habit to enjoy and consume the commodities which include everything that lie outside the range of self. A moment's reflection on depleting resources, however, tells that in the long run this strategy would be of little help.

By increasing our needs we often invite troubles. The common mind set is one of celebrating the egoic self at the cost of everything else including nature. This limited sense of exclusive self is the root cause of selfishness, hatred, aggression and competition that culminates in violence. Unfortunately the insatiable hunger of today's man is considered as a marker of progress and development. Under these circumstances a confrontation between man and man as well as between man and nature has become inescapable. The contemporary international scenario indicates that the imbalanced socio-political structure and attempts at monopolizing the resources through economic imperialism are causing large scale violence.
The myopic vision, however, fails to recognize the extant limitations of individual or egoic self. The emphasis on differences and uniqueness of self, rather than similarity and connectivity is congruent with psychology's modernist assumptions. This kind of self aspires independence. The desire to be independent, absolves us from social responsibility and allows to become selfish. People find connectivity as a burden. 'Me' and 'mine' become central and social interest recedes to background. This kind of thinking promotes violence at all levels of human interaction.

As stated earlier non-injury or refraining from causing hurt or harm to all beings is Ahimsa or non-violence. It requires self regulation embedded in an articulation of interdependent mode of life. Non-violence recognizes that self and other are not mutually exclusive. Instead they are connected and complimentary to each other. The harmony and peace are possible if we are loved and revered and therefore we need to continuously practice non-violence. Non-violence has two-pronged functioning. It not only opposes killing, aggression, enmity, jealousy, hatred, suppression and exploitation but also enhances cooperation, friendliness, harmony, peace, protection, and restoration of dignity in society. Acting non-violently enriches life of all living beings.

The practice of non-violence therefore demands good will, rational thinking, self control and commitment. Peace and harmony which are essential for development and growth may happen only if there is non-violence. Using non-violence helps resolving conflict through attitude change without external imposition. In recent history there are many illustrations of the use of non-violence. Mahatma Gandhi used a variety of non-violent practices (e.g. noncooperation, self-determination of behavior, non-violent non-cooperation, constructive work, civil disobedience, cooperation) for many social purposes including removal of untouchability, Hindu-Muslim cooperation, and fighting with British colonial regime. He demonstrated that a viable collective life is possible only through interdependence, sharing, cooperation, and responsibility. Instead of devaluation of others by making them as scapegoat or blaming, the practice of non-violence expands the scope of mutuality through active compassion. Also the basic human needs such as security, positive identity, and connectivity demand that we must transcend the boundaries of ego and relate to others. To this end we need to raise children with warmth and affection and through inclusive caring. This would create a balance of connectivity and authority and a sense of moral courage. Psychology may contribute to foster the creation of communities that help and allow collective living-based on the qualities of care, peace, empathy, respect, and goodness.

Girishwar Misra Editor 